\title{
Soil corrosivity to the buried-pipes used in Lalitpur, Kathmandu Valley, Nepal
}

\author{
Shrawan K. Regmi ${ }^{1}$, Kumar P. Dahal ${ }^{2}$ and Jagadeesh Bhattarai ${ }^{2^{*}}$ \\ ${ }^{1}$ Department of Chemistry, Tri-Chandra Multiple Campus, Tribhuvan University, Kathmandu, Nepal \\ ${ }^{2}$ Central Department of Chemistry, Tribhuvan University, Kathmandu, Nepal
}

\begin{abstract}
Six soil parameters (moisture content, $\mathrm{pH}$, resistivity, oxidation-reduction potential, chloride and sulfate) of 23 samples were analyzed using standard methods for their corrosive nature towards the buried galvanized-steel and cast-iron pipes used to supply drinking water in three areas (Tikathali, Imadol$\mathrm{KA}$ and Imadol-KHA) of Lalitpur district of Kathmandu Valley. Amounts of these six soil parameters in the collected 23 samples were found to be of $11-37 \%$ moisture content, $6.1-8.4 \mathrm{pH}, 0.3330 \times 10^{4}-$ $4.7620 \times 10^{4} \mathrm{Ohm} . \mathrm{cm}$ resistivity, $317-553 \mathrm{mV}$ (SHE) oxidation-reduction potential, 14-75 ppm chloride and 56-176 ppm sulfate contents. These findings indicated that most of soil samples collected from the study areas of Lalitpur district of Nepal are found to be mildly corrosive and less corrosive nature of soils on the buried galvanized-steel and cast-iron pipes used for the supply of drinking water. The use of non-conducting materials like gravel/sand around the buried-pipes, before burying them in the study areas seems to be effective to control such corrosion and to increase life time of the pipes.
\end{abstract}

Key words: Buried-metallic pipes, Chloride, Resistivity, Soil corrosion, Sulfate

\section{Introduction}

The degradation of the buried-metallic materials due to different soil parameters is known as soil corrosion (Bhattarai, 2010; Revie \& Uhlig, 2008). There is a high degree of environmental and economic consequences of the soil corrosivity due to a failure of the buried-metallic pipes used to supply the drinking water natural gas and crude oil all over the world. In general, the corrosivity of the buried-metallic pipes can be explained on the basis of two categories of soil; one is disturbed soil and the next is undisturbed soil. However, it was reported that the cor rosive nature of the undisturbed soil is negligible as compared to that of the disturbed soil (Norin \& V inka, 2003). The cor rosion rate of the buriedmetallic pipes in the disturbed soil is influenced by a number of corrosion related soil parameters like resistivity or conductivity, $\mathrm{pH}$, chloride, sulfate, sulphide ions, soil moisture, oxidationreduction (redox) potential, or ganic matters and so on. Quantitatively, actual cor rosion rate of such buried-materials cannot be predicted by measuring one of these main soil parameters, because of its complex nature. Hence, relative corrosion risk of soil towards the buried-metallic materials could be determined by analyzing the most important soil parameters.

Corrosion of the metallic materials in soil is a multi-scale process, which is highly influenced by film/droplet formation on the metal or alloy, the geometry and liquid phase chemistry of such films as well as the development of oxide layers on the metal or alloy surface (Cole \& Marney, 2012). Acidic soil having pH less than 5 represents serious corrosion risk to the buried-metallic materials such as galvanized-steel, cast-iron and zinc coating and so on. Neutral $\mathrm{pH}$ around 7 is the most desirable to minimize the corosion damage of the most buried-metallic materials by soils. It was reported that the soil $\mathrm{pH}$ ranges from 5 to 8.5 is not usually considered to be a problem for corrosion for the buried-metallic materials (Bhattarai, 2010; Revie \& Uhlig, 2008).

The amount of moisture content in soil is one of the ley parameters for showing high corrosivity towards the buried-metallic materials. Soil with the poorest drainage was reported to be the most corrosive for the buried-metallic materials, while a well drained soil was found to be less corrosive (Logan \& Growsky, 1931; Logan, 1945; Denison \& Romanoff, 1952; Romanoff, 1957). On the other hand, dry or almost dr y soil shows ver y high resistivity or low conductivity and hence it is considered to be less cor rosive for the buried-metallic materials. It was reported that the soil resistivity was decreased rapidly with increasing the moisture content until the saturation point was reached (Romanoff, 1957; Booth et al., 1967; Benmoussa et al., 2006). This may be the reason for not

*Corresponding author, email address: bhattarai_05@yahoo.com 
showing change of resistivity with moisture content more than $60 \%$ in soil (Romanoff, 1957).

Soil resistivity is the inverse of soil conductivity and it is one of the broad indicators for the soil cor rosivity towards the buriedmetallic materials (Revie \& Uhlig, 2008). There is good correlation between the soil resistivity and corrosion rate of the buried-metallic materials. Higher the concentration of salts of ions present in soil, higher is the electrical conductance and hence the soil resistivity is low. The corrosion rate of the buried-metallic materials by soil is generally high, if the soil shows low resistivity. The soil resistivity is also affected by the presence of the moisture content in soil. Dry soil has extremely high resistivity and hence the sandy soils that easily drain water away are typically less cor rosive while the clay-like soils that hold more water have low resistivity and are typically corrosive for buried-metallic materials.

The oxidation-reduction potential (ORP) or redox potential of the soils is significant, because it determines the stability of the buriedmetallic materials. The ORP value greater than about $+100 \mathrm{mV}$ (SHE) indicates a high oxygen level in soil. The ORP values less than about $+100 \mathrm{mV}$ (SHE) may indicate that soil condition is favourable for anaerobic microbial activity due to less oxygen available in soil. Iron pipe buried in an anaerobic soil (low ORP) will tend to not $r$ ust, because the soil will not contain any free oxygen, which is needed for the formation of rust on the surface of iron and its alloys. On the other hand, the combination of anaerobic conditions and sulphur in the form of sulfate or sulfide can lead to soil corrosion. Soil microbes can convert the sulfide formed from sulfate into sulfuric acid, if conditions become more oxidized (Thierry \& Sand, 2002). The ORP value generally affects the types of microbiologically induced cor rosion (MIC) or biocorrosion that occurs in soils (Ar zola et al., 2006; Li, 2003; Li et al., 2001).

Chloride content in soil plays a major role in the cor rosivity of buried-metallic materials (Jack \& Wilmott, 2011; Maslehuddin et al., 2008). It destroys the stable protection layer that can naturally form on the surface of the buried-metallic materials, exposing the unprotected material sur face for further cor rosion. High concentrations of sodium chloride in poorly drained soil mak e the soil very corrosive towards the buried-metallic materials. The sulfate ion is the naturally occur ring form of sulphur in soils, although it is less cor rosive as compared to the chloride ion. It can be readily converted into highly cor rosive sulphides by anaerobic sulfate reducing bacteria, SRB (Hamilton, 2010; Jack, 2002; Shreir et al., 1994). It is meaningful to mention here that the soils are generally considered to be mildly cor rosive if the sulfate and chloride contents are below 200 ppm and 100 ppm, respectively, for soils with $5.0-8.5 \mathrm{pH}$ and the resistivity greater than 3,000 Ohm.cm (Bhattarai, 2010; Revie \& Uhlig, 2008). Study of corrosion behaviour of the underground pipelines in soil is of major importance in the field of corrosion science, because millions of kilometres of the buried-pipelines are used to supply drinking water, petroleum products and other hazardous chemicals all over the world (Ricker, 2010). USA has over 3.7 million kilometres of pipelines crossing the countr y transporting natural gas and hazardous liquids from sources to consumers (Rick er, 2010). Similarly, it was reported that about $150,000 \mathrm{~km}$ of ferrous pipelines used to supply the drinking water in Australia were also affected by localized corrosion leading to leakage (WSAA, 2009). A total buried-pipeline lengths of about $2000 \mathrm{~km}$, valued at almost 700 million Euro used in Gutenberg of Sweden alone were reported that the annual cost of three million Euro , almost $50 \%$ of the damage can be related directly or indirectly to soil corrosion (Norin \& Vinka, 2003). Every year, $\$ 200$ million is spent on renewing Iron water mains in Canada. The most common corrosion failure mechanism for the buried-fer rous pipes is localized cor rosion leading to leaking (Ricker, 2010; WSAA, 2009). There is therefore a great need to deter mine the causes of soil cor rosion, and to establish a quick and easy method of evaluating the corrosivity of soils.

In Nepal, the supply of drinking water from water reser voirs to distribution terminals and to consumers is mostly through the buried-galvanized steel and cast-iron pipes. In this context, it is very urgent to investigate the effects of different soil parameters that affect the cor rosive nature of soil on the buried-galvanized steels and cast-iron pipelines used to supply city water in Kathmandu Valley and other big cities of Nepal. Therefore, the main objective of this research work is to establish the corrosive nature of soils collected from three residential areas, i.e., Tikathali, Imadol-KA and Imadol-KHA of $\mathrm{L}$ alitpur district of $\mathrm{K}$ athmandu Valley by measuring most effective six soil parameters: $\mathrm{pH}$, moisture content, resistivity, ORP, chloride and sulfate contents. An attempt was made to cor relate these soil parameters with the standard values established by A STM and NACE for comparing the soil corrosivity towards the buried-metallic pipes.

\section{Materials and methods}

Total 23 soil samples (seven samples from Tikathali, eight from each Imadol-KA and Imadol-KHA areas) were collected from depth of about $1 \mathrm{~m}$ from the ground level in the months of $\mathrm{F}$ ebruary and May. The soil sample was taken in an air tight poly vinyl bag so that the moisture remained same till the time of moisture content analysis in the laborator y. All three sampling sites are located in Lalitpur district of Nepal (Fig. 1).

A digital $\mathrm{pH}$ meter was used to determine the $\mathrm{pH}$ at 1:2 soil-water extract of each soil samples in accordance with the ASTM G51-95 (2012) standards. Moisture content in soil was determined using weight loss method in accordance with the ASTM D4959-07 (2007) standards. The soil resistivity is actual bulk resistivity of soil influenced by types of soil, moisture content, concentration of different dissolved salts, degree of compactness and temperature. 


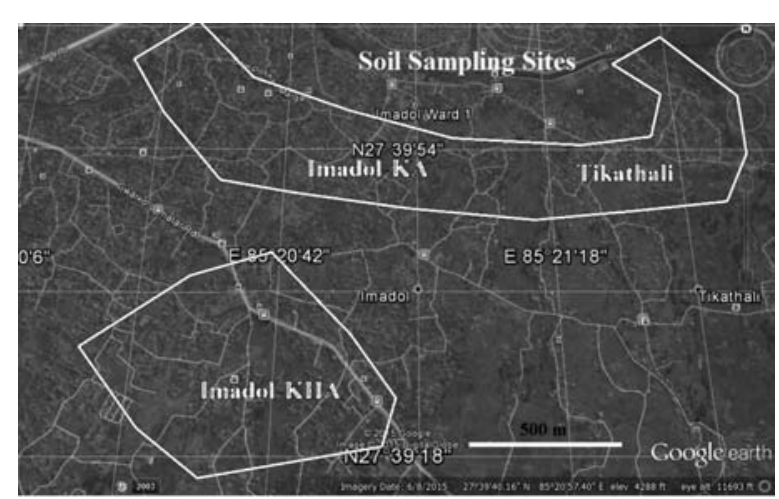

Fig. 1 Satellite map of sampling area

Since the soil resistivity was not measured at the sampling sites, all these affecting factors except types, moisture content and dissolved salts are different from their in-situ values. Hence, in this work, all efforts were made to ensure uniformity among the resistivity tests performed in the laboratory. All soil samples were tested at room temperature at $\left(25 \pm 1^{\circ} \mathrm{C}\right)$ which remained constant and an effort was made to compact the soils to the same degree into the square soil box. The conductivity bridge was used to determine the electrical conductivity at 1:2 soil-water extract in accordance with the ASTM G187-05 (2005) standards. The soil resistivity (bulk/saturated paste) was calculated from the conductivity measurement.

The oxidation-reduction potential (ORP) of the soil samples was measured with the help of a digital potentiometer in accordance with the ASTM G200-09 (2009) standards. The platinum wire and saturated calomel electrodes (SCE) were used as working and reference electrode, respectively. The recorded ORP values vs SCE was converted to reference value of the saturated hydrogen electrode (SHE). Argentometric titration was used to determine the amount of chloride content in soil. Chloride content, in the 1:2 soil-water extract, was determined by titrating the soil extract against standard silver nitrate solution using potassium chromate as an indicator. Gravimetric method was used to estimate the amounts of sulfate content in soil samples. The details of these all methods are also discussed elsewhere (Dahal et al., 2014; Dhakal et al., 2014; Bhandari et al., 2013; Bhattarai, 2013a, 2013b; Gautam \& Bhattarai, 2013; Bhattarai et al., 2016).

\section{Results and discussion \\ Moisture content in soil}

The moisture content in all 23 soil samples collected from present sampling areas was found in the range of $11-37 \%$ ( $\mathrm{F}$ ig. 2). In general, clay-like and humus soils hold maximum moisture content than sandy and rocky soils. Among 23 soil samples, 10 samples contained 20\% or less moisture content, while remaining 13 samples contained $21-40 \%$ moisture content. These results revealed that the soil samples collected from the sampling sites in this study are assumed to be mildly corrosive and less corrosive towards the buried-galvanized steels and cast-iron pipelines.

\section{Soil $\mathbf{p H}$}

All 23 soil samples were found to be slightly acidic, neutral or slightly alkaline in nature having the $\mathrm{pH}$ values ranges from 6.18.4 (Fig. 3). It is meaningful for mentioning here that soil samples having the $\mathrm{pH}$ range of 6.5-7.5 are considered to be less corrosive towards the buried galvanized-steel and cast-iron pipes. Therefore, all soil samples are assumed to be less corrosive to mildly corrosive for the buried galvanized-steel and cast-iron pipes based on the observed soil $\mathrm{pH}$ values.

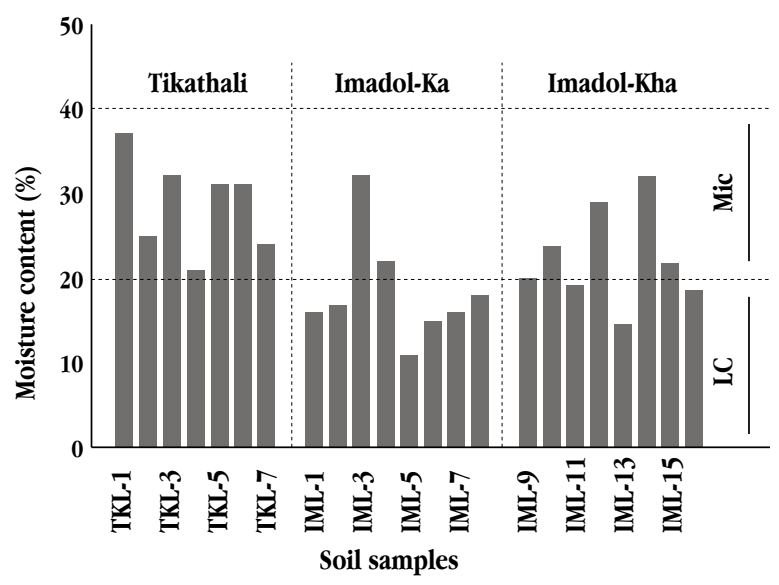

Fig. 2 Moisture content in the soil samples (LC = less corrosive; $\mathrm{MiC}=$ mildly corrosive)

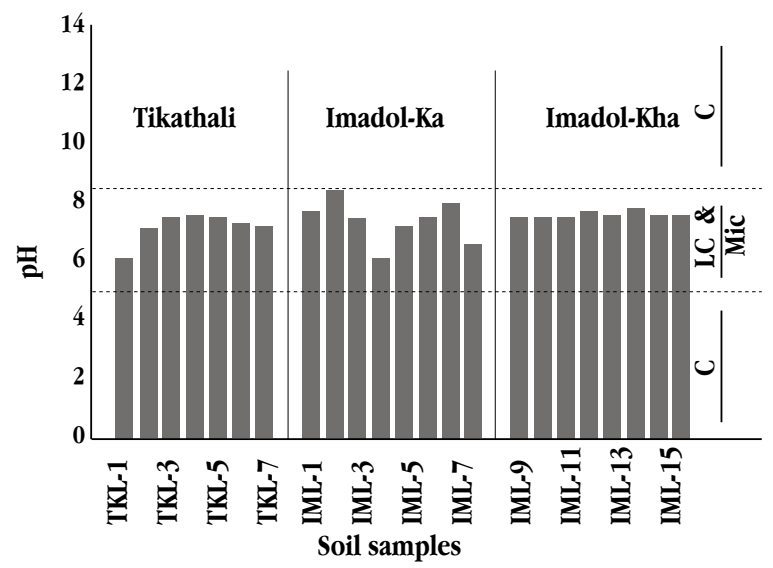

Fig. $3 \mathrm{pH}$ in the soil samples ( $\mathrm{LC}=$ less corrosive; $\mathrm{MiC}=$ mildly corrosive; $\mathrm{C}=$ corrosive) 


\section{Soil resistivity}

The resistivity of all 23 soil samples collected from Tikathali and Imadol areas of $\mathrm{L}$ alitpur district was found to be ranged from $3.33 \times 10^{3}$ to $4.762 \times 10^{4}$ Ohm.cm (Fig. 4). Among these 23 soil samples, six soil samples have the soil resistivity more than $2.000 \times 10^{4} \mathrm{Ohm} . \mathrm{cm}$, eight samples have the soil resistivity between $1.000 \times 10^{4}$ and $2.000 \times 10^{4} \mathrm{Ohm} . \mathrm{cm}$, five samples have the soil resistivity between $5.000 \times 10^{3}$ and $1.000 \times 10^{4} \mathrm{Ohm} . \mathrm{cm}$, while remaining four soil samples from Imadol-KHA area have less than $5.000 \times 0^{3} \mathrm{Ohm} . \mathrm{cm}$ resistivity (Fig. 4). These results revealed that most of the soil samples collected from Tikathali and Imadol areas of $\mathrm{L}$ alitpur district are considered to be mildly to less corrosive in nature for the buriedmetallic materials according to the ASTM classifications (Table 1) (Escalante, 1989; Robinson, 1993). However, four soil samples (IML10, IML-12, IML-14 and IML-15 from the Imadol-KHA area) are considered to be cor rosive having the soil resistivity less than $5.000 \times 10^{3}$ Ohm.cm.

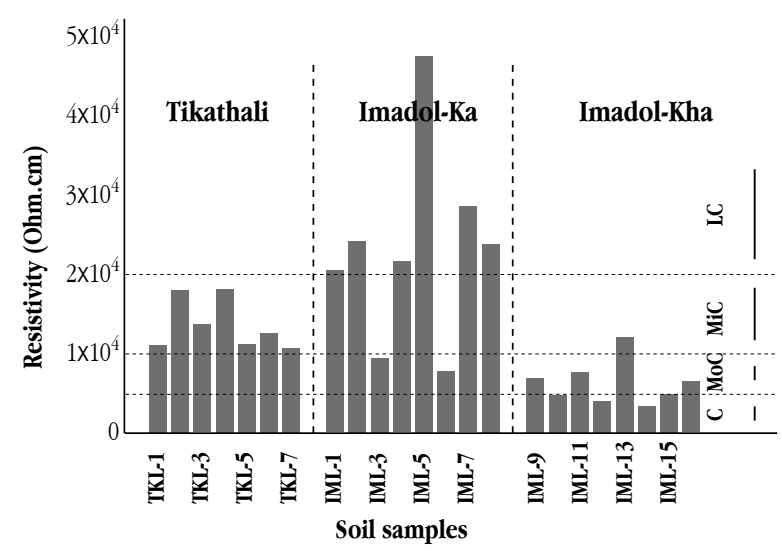

Fig. 4 Soil resistivity of the soil samples (LC=less corrosive; $\mathrm{MiC}=$ mildly corrosive; $\mathrm{MoC}=$ moderately corrosive; $\mathrm{C}=$ corrosive)

\section{Oxidation-reduction potential of soil}

It was found that the ORP of all 23 soil samples found in the range of +317 to $+553 \mathrm{mV}$ vs SHE (F ig. 5). Among the collected soil samples, 13 samples have ORP value in the range of +200 to +400 $\mathrm{mV}$ vs SHE are considered to be mildly corrosive towards the buried galvanized-steel and cast-iron pipes used to supply drinking water in the study areas of $\mathrm{K}$ athmandu Valley. On the other hand, the remaining 10 soil samples are considered to be less cor rosive, because they showed the ORP more than $+400 \mathrm{mV}$ vs SHE (F ig. 5). These results are drawn on the basis the Johes' classification (Table 2) (Jones, 1996; Starkey \& Wight, 1983).
Table 1 Rating of soil cor rosivity towards the buried-metallic pipes based on the soil resistivity, chloride and sulfate contents in soil (Escalante, 1989; Robinson, 1993)

\begin{tabular}{cl}
\hline \multicolumn{1}{c}{ Soil Parameter } & \multicolumn{1}{c}{ Soil Corrosivity } \\
\hline 1.Soil Resistivity (Ohm.cm) & \\
$>20,000$ & Less Corrosive (LC) \\
$10,000-20,000$ & Mildly Corrosive (MiC) \\
$5,000-10,000$ & Moderately Corrosive (MoC) \\
$<5,000$ & Corrosive (C) \\
2. Chloride Content (ppm) & \\
$<50$ & Less Corrosive (LC) \\
$50-100$ & Mildly Corrosive (MiC) \\
$>100$ & Corrosive (C) \\
3. Sulfate Content (ppm) & \\
$<100$ & Less Corrosive (LC) \\
$100-200$ & Mildly Corrosive (MiC) \\
$>200$ & Corrosive (C) \\
\hline
\end{tabular}

\section{Chloride content in soil}

The chloride content in all soil samples was found in the range of 14-75 ppm (Fig. 6). Among these 23 soil samples, 18 samples have less than $50 \mathrm{ppm}$, while five samples have chloride content in the range of 50-100 ppm (Fig. 6). These results revealed that all the soil samples collected from Tikathali, Imadol-KA and Imadol-KHA areas of Lalitpur district are less corrosive and mildly corrosive towards the buried galvanized-steel and cast-iron pipes used to supply drinking water in the study areas, because the soils containing less than 100 ppm chloride content and more than 5,000 Ohm.cm soils resistivity are categorized as the mildly corrosive and less cor rosive soils towards the buried-metallic materials based on the ASTM classification (Table 1) (Escalante, 1989; Robinson, 1993).

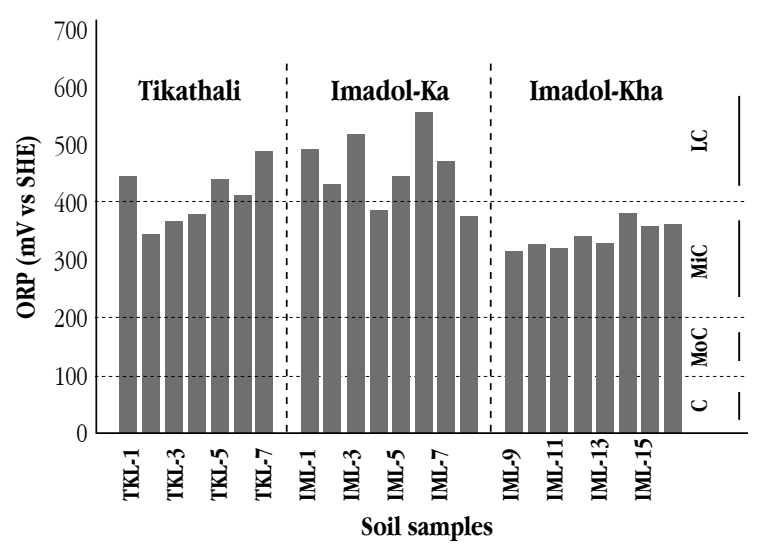

Fig. 5 Oxidation-Reduction Potential of the soil samples (LC = less corrosive; $\mathrm{MiC}=$ mildly corrosive; $\mathrm{MoD}=$ moderately corrosive; $\mathrm{C}=$ corrosive) 
Table 2 Rating of soil cor rosivity towards the buried-metallic pipes based on ORP of soil (Jones, 1996; Stark ey \& Wight, 1983)

\begin{tabular}{cl}
\hline ORP (mV vs SHE) & \multicolumn{1}{c}{ Soil Corrosivity } \\
\hline Soil Resistivity (Ohm.cm) & \\
$>400$ & Less Corrosive (LC) \\
$201-400$ & Mildly Corrosive (MiC) \\
$100-200$ & Moderately Corrosive (MoD) \\
$<100$ & Corrosive (C) \\
\hline
\end{tabular}

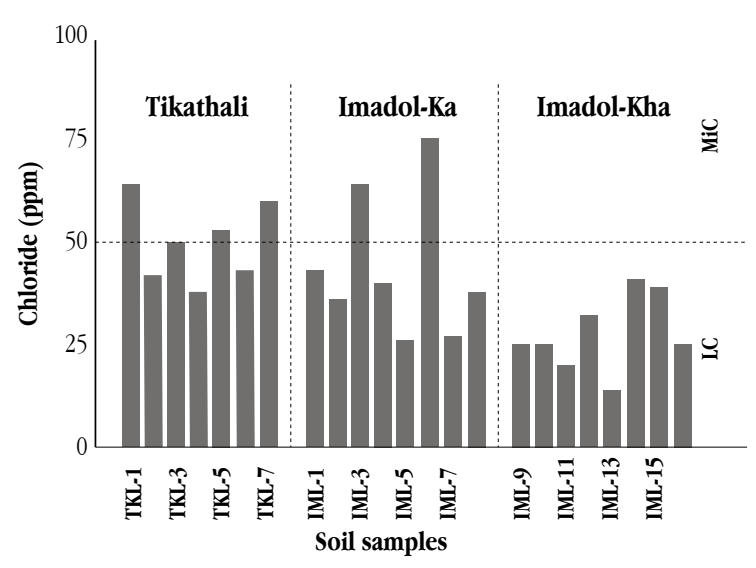

Fig. 6 Chloride content in soil samples (LC = less cor rosive; $\mathrm{MiC}=$ mildly corrosive)

\section{Sulfate content in soil}

Among the 23 soil samples, 19 samples contained the sulfate in the range of 100-200 ppm and the remaining four soil samples contained less than $100 \mathrm{ppm}$ sulfate (F ig. 7). It clearly showed that the sulfate content in four soil samples contained more than $200 \mathrm{ppm}$ (the upper limit for mildly cor rosive nature of soils). Consequently, almost all soil samples (19 out of 23) are considered to be mildly cor rosive and remaining four are considered to be less corrosive for the buried galvanized-steel and cast-iron pipes (Table 1) (Escalante, 1989; Robinson, 1993). Soils containing less than 200 ppm of sulphate was considered as mildly and/or corrosive (Escalante, 1989; Robinson, 1993).

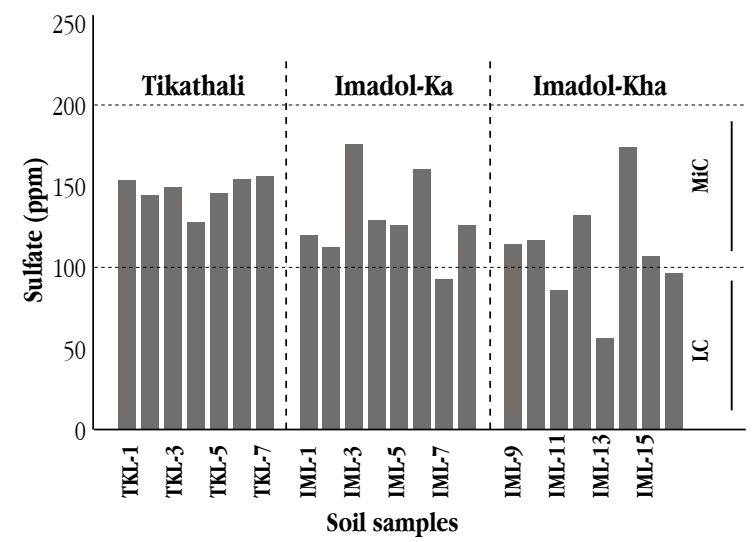

Fig. 7 Sulphate content in soil samples (LC = less cor rosive; $\mathrm{MiC}=$ mildly corrosive)

\section{Conclusions}

Following conclusions are drawn from the above results and discussion on the corrosive nature of the 23 soil samples collected from Tikathali, Imadol-KA and Imadol-KHA areas of Ialitpur district. 1. All the collected soil samples contained less than $40 \%$ moisture content which is assumed to be mildly cor rosive and less corrosive nature towards the buried galvanized-steel and castiron pipes.

2. The soil $\mathrm{pH}$ value of all the soil samples was found to be within the limits of 6.1-8.4 showing mildly corrosive and less corrosive towards the buried galvanized-steel and cast-iron pipes.

3. A very high soil resistivity of $5.000 \times 10^{3} \mathrm{Ohm}$.cm or more was found for 19 soil samples except four samples from ImadolKHA area supports the moderately corrosive to less corrosive nature of soils collected from the present study areas.

4. All soil samples have the oxidation-reduction potential values above $200 \mathrm{mV}$ (SHE), which shows the mildly cor rosive and less corrosive nature of soil towards the buried galvanized-steel and cast-iron pipes.

5. All the soil samples contained less than $100 \mathrm{ppm}$ chloride, less than $200 \mathrm{ppm}$ sulfate and hence they are considered to be mildly corrosive and less corrosive in nature towards the buried galvanized-steel and cast-iron pipes used to supply drinking water.

\section{Acknowledgements}

Authors would like to acknowledge the Head of Central Department of Chemistry, Tribhuvan University and the M. Sc. Programme Coordinator of the Department of Chemistry, Tri-Chandra Multiple Campus, Kathmandu for providing the research facilities to conduct this research. One of the authors (KP Dahal) would lik e to acknowledge Nepal Academy of Science and Technology (NAST) for providing Ph. D. scholarship.

\section{References}

Arzola, S., Mendoza-Flores, J., Duran-Romero, R., \& Genesca, J. (2006). Electrochemical behaviour of API X70 steel in hydrogen sulphide-containing solutions. Corrosion, 62, 433-443.

ASTM G51-95 (2012). Standard test method for measuring pH of soil for use in corrosion testing. In Annual Book of ASTM Standards, Vol. 03.02, American Society for Testing and Materials.

ASTM G200-09 (2009). Standard test method for measurement of oxidation-reduction potential (ORP) of soil. In Annual Book of ASTM Standards, Vol. 03.02, American Society for Testing and Materials.

ASTM D4959-07 (2007). Standard test method for determination of water (moisture) content of soil by direct heating. In Annual Book of ASTM Standards, Vol. 03.02, American Society for Testing and Materials.

ASTM G187-05 (2005). Standard test method for measurement of soil resistivity using two-electrode soil box method. In Annual Book of ASTM Standards, Vol. 03.02, American Society for Testing and Materials. 
Benmoussa, A., Hadjel, H., \& Traisnel, M. (2006). Corrosion behaviour of API 5L X-60 pipeline steel exposed to near-neutral pH soil simulating solution. Materials and Corrosion, 57, 771777.

Bhandari, P.P., Dahal, K.P., \& Bhattarai, J. (2013). The corrosivity of soils collected from Araniko Highway and Sanothimi areas of Bhaktapur, Nepal. Journal of Institute of Science and Technology, 18(1), 71-77.

Bhattarai, J. (2010). Frontiers of Corrosion Science. $1^{\text {st }} \mathrm{Ed}$., Kathmandu, Kshitiz Publication.

Bhattarai, J. (2013a). Investigation of soil Parameters for their corrosivity on buried galvanized steel pipelines used in Kathmandu valley (Unpublished research report). Kathmandu, Nepal Academy of Science and Technology-NAST, pp. 1-41.

Bhattarai, J. (2013b). Study on the corrosive nature of soil towards the buried-structures. Scientific World, 11, 43-47.

Bhattarai, J., Paudyal, D., \& Dahal, K.P. (2016). Study on the soil corrosivity towards the buried-metallic pipes in Katbmandu and Chitwan valley. In Proceeding of the $17^{\text {th }}$ Asian Pacific Corrosion Control Conference (APCCC17), 27-30 January, 2016, IIT Bombay, Mumbai, India. Paper No. 17039, 1-12.

Booth, G.H., Cooper, A.W., \& Cooper, P.M. (1967). Criteria of soil aggressiveness towards buried metals: II- Experimental methods. British Corrosion Journal, 2, 109-113.

Cole, I.S., \& Marney, D. (2012). The science of pipe corrosion: a review of the literature on the corrosion of ferrous metals in soils. Corrosion Science, 56, 5-16.

Dahal, K.P., KC, D., \& Bhattarai, J. (2014). Study on the soil corrosivity towards the buried water supply pipelines in Madhyapur Thimi municipality; Bhaktapur. BIBECHANA, 11, 94-102.

Denison, I.A., \& Romanoff M. (1952). Corrosion of galvanized steel in soils. Journal of Research of the National Bureau of Standards, 49, 299-314.

Dhakal, Y.R., Dahal, K.P., \& Bhattarai, J. (2014). Investigation on the soil corrosivity towards the buried water supply pipelines in Kamerotar town planning areas Bhaktapur, Nepal. BIBECHANA, 10, 82-91.

Escalante, E. (1989). Effect of soil characteristics on corrosion. In V. Chaker and J.D. Palmer (eds), Concepts of Underground Corrosion. Michigan, American Society for Testing and Materials, 1989, pp. 81-91.

Gautam, M., \& Bhattarai, J. (2013).Study on the soil corrosivity towards the buried-structures in soil environment of Tyanglaphant-Tribhuvan University Campus-Balkhu areas of Kirtipur. Nepal Journal of Science and Technology, 14, 6572.

Hamilton, W.A. (2010). Microbiologically influenced corrosion as a model system for the study of metal microbe interactions. The Journal of Bio-adbesion and Bio-film Research, 19, 6576.
Jack, T.R., \& Wilmott, M.J. (2011). Corrosion in soils. In R.W. Revie (ed.) Uhlig's Corrosion Handbook. $3^{\text {rd }}$ Edition, New Jersey, The Electrochemical Society Inc. \& John Wiley \& Sons Inc., pp. 333-349.

Jack, T.R. (2002). Biological corrosion failures. In Failure Analysis and Prevention. Materials Park, OH., ASM Handbook, ASM International, 11, pp. 881-898.

Jones, D.A. (1996). Principles and Prevention of Corrosion. $2^{\text {nd }}$ Edition, Prentice Hall, 1996.

Li, S.Y., Kim, Y.G., Jeon, K.S., Kho, Y. T., \& Kang, T. (2001). Microbiologically influenced corrosion of carbon steel exposed to anaerobic soil. Corrosion, 57, 815-828.

Li, S.Y. (2003). Corrosion behaviour of carbon steel influenced by sulfate-reducing bacteria in soil environments (Unpublished Ph.D. thesis), Seoul National University, Seoul.

Logan, K.H. (1945). Underground corrosion. In National Bureau of Standards Circular 450. Washington D.C., the United States Department of Commerce, Government printing Office.

Logan, K.H., \& Growsky, V.A. (1931). Rates of corrosion and pitting of bare ferrous specimens. In Soil corrosion studies 1930. Washington D.C., the United States Department of Commerce, Government Printing Office.

Maslehuddin, M., Al-Zahrani, M.M., Ibrahim, M., Al-Methel, M.H., \& Al-Idi, S.H. (2008). Effect of chloride concentration in soil on reinforcement corrosion. Journal of Construction and Building Materials, 21, 1825-1832.

Norin, M., \& Vinka, T.G. (2003). Corrosion of carbon steel in an urban environment. Materials and Corrosion, 54, 641-651.

Revie, R.W., \& Uhlig, H.H. (2008). Corrosion and corrosion control; an introduction to corrosion science and engineering. $4^{\text {th }}$ Edition, New Jersey, John Wiley and Sons Inc.

Ricker, R.E. (2010). Analysis of pipeline steel corrosion data from NBS (NIST) studies conducted between 1922-1940 and relevance to pipeline management. , 115, 373-392.

Robinson, W. (1993). Testing soil for corrosiveness. Materials Performance, 32, 56-58.

Romanoff, M. (1957). Underground corrosion. In National Bureau of Standards Circular 579. Washington D.C., the United States Department of Commerce, Government Printing Office.

Shreir, L.L., Jermann, R.A., \& Burstein, G.T (1994). Corrosion Metal/Environment Reactions. $3^{\text {rd }}$ Edition, Oxford, Butterworth Heinemann.

Starkey, R.L., \& Wight, K.M. (1983). Anaerobic corrosion of iron in soil. American Gas Association Bulletin, 17, 11-13.

Thierry, D., \& Sand, W. (2002). Microbiologically influenced corrosion. In P. Marcus (Ed.), Corrosion Mechanisms in Theory and Practice, New York, CRC Press, 563-603.

WSAA (2009). National Performance Report-Urban Water UtilitiesPart C. Australia, Water Services Association of Australia, 2009.

\section{缕 TU-CDES}

